\title{
O PRZEKŁADZIE TYTUŁÓW BUŁGARSKICH PRZEPISÓW KULINARNYCH NA JEZZYK POLSKI
}

\section{Translation of Bulgarian Recipes' Titles into Polish}

Keywords: recipe, bulgarian language, polish language, translation, title

Contact: Uniwersytet Śląskiw Katowicach; a.wojnarowska93@gmail.com

Przedmiotem niniejszych badań jest zilustrowanie możliwości przekładu wybranych tytułów bułgarskich współczesnych przepisów kulinarnych na język polski, które ze względu na swoja strukturę i treść mogą zachęcać zarówno do teoretycznych rozważań translatologicznych jak i praktycznych działań związanych z procesem przekładu. Przepisy zaczerpnięte zostały z bułgarskich książek kucharskich, blogów i stron o tematyce kulinarnej. Opisany proces a także produkt przekładu poszczególnych nazw przepisów jest autorskim działaniem wynikającym z wyboru tłumacza.

Przepis kulinarny jest charakterystycznym tekstem, składającym się z reguły z trzech komponentów: tytułu, wykazu składników oraz sposobu przygotowania. Tytuł przepisu kulinarnego pełni funkcję identyfikacyjną oraz funkcję wyznacznika delimitacyjnego, którym de facto jest. Tytuł jako wyznacznik delimitacyjny stanowi podstawę do zrozumienia i interpretacji tekstu, pomimo że nie musi być elementem jego treści.

Przepis kulinarny jako tekst posiada swój tytuł, natomiast dana potrawa jest określona swoją nazwą, często jednak się zdarza, że tytułem przepisu jest nazwa samej potrawy.

Claude Duchet rozróżnia w tytule trzy podstawowe segmenty: tytuł główny, tytuł sekundarny (poprzedzany najczęściej spójnikiem albo, czyli lub wyróżniany graficznie) oraz podtytuł (Żarski 2008: 111). Anna Duszak umieszcza tytuły wśród tekstowych wskaźników orientacji na strategicznej pozycji tekstowej, gdyż celem tytułu jest orientowanie odbiorcy w przestrzeni dyskursu. Tytuły, podobnie jak podtytuły, śródtytuły, dzięki swojej inicjalnej pozycji w całym tekście zapowiadają treści kolejnych komponentów tekstu i intensyfikują tym samym oczekiwania odbiorcy 
względem celów komunikacyjnych nadawcy (Żarski 2008: 114). Pragmatyczna i kontekstowa rola tytułu stanowi punkt odniesienia komunikatu, przez co wpływa na zrozumienie tekstu (Żarski 2008: 111).

W tytule ważna jest jego forma. Współczesne tytuły przepisów kulinarnych, zarówno polskie, jak i bułgarskie, są zwięzłe i tematycznie skondensowane. Długość tytułu decyduje o pojemności informacyjnej (Żarski 2008: 111). Przepis może być uzupełniony określeniem sposobu wykonania, nazwą regionu, z którego pochodzi, może też być nawą własną. W tworzeniu tytułów przepisów panuje pełna swoboda. Tytuł może leksykalnie odzwierciedlać rzeczywistość, jaką jest konkretne danie, można go także ująć w sposób metaforyczny. Wówczas przepis nabiera charakteru artystycznego, zachęcając odbiorcę do zagłębienia się w lekturę w celu uzyskania informacji o daniu.

Tytuły przepisów kulinarnych przejawiają różna strukturę zarówno w języku polskim, jak i bułgarskim, ale można je wzajemnie porównać, znajdując elementy zbieżne. Nie brakuje takich, które zawierają w sobie jednowyrazową nazwę, np. пататник, гювеч, капама. Najbardziej typowe wydają się te, w których występuje nazwa głównego składnika potrawy np. filet z kaczki, stek wołowy, фазул чорба, шкембе чорба, пилешка суnа. Niektóre tytuły informują o składniku akcesoryjnym np. kotlet ze szpinakiem, сарми с лозови листа, качамак с картофи. Tytuł może także informować o sposobie przygotowania w ujęciu obróbki termicznej odpowiednio zestawionych produktów (Żarski 2008: 164), np. gotowane pulpety, pstrag smażony варено жито, кюфтета на скара lub w ujęciu kategoryzacji klasyczne, domowe, prekursorskie np. rosót doтоwy, пилешка супа по класическа рецепта. Tytuły implikują informację odnoszącą się do listy zakupów. Odbiorca, czytając tytuł wie, czego on dotyczy. Znaczna część przepisów, co widać w książkach kucharskich, w których przepisy segregowane są tematycznie, posiada główny leksykalny nośnik znaczenia - nomen regens. Jest to rzeczownik semantycznie nadrzędny wobec innych rzeczowników i atrybutów oraz wspólny dla wszystkich członów nazwy (Żarski 2008: 164), np. zupa pomidorowa, ogórkowa, pieczarkowa.

Nazwy potraw w swojej charakterystycznej strukturze oprócz rzeczownika nadrzędnego często posiadają także leksem atrybutywny, którym jest najczęściej przymiotnik, natomiast oprócz przymiotnika funkcję atrybutywną mogą pełnić także inne klasy leksemów ${ }^{1}$.

\footnotetext{
${ }^{1}$ Podana klasyfikacja polskich i bułgarskich tytułów przepisów kulinarnych została przedstawiona na podstawie klasyfikacji W. Żarskiego (Żarski 2008: 164).
} 
- W funkcji leksemu atrybutywnego występują zadiektywizowane przysłówki z przyimkiem po, np. placek po wegiersku, качамак по овчарски, пататник по златоградски.

- W tytułach polskich, w funkcji leksemów atrybutywnych występują także rzeczowniki w dopełniaczu z przyimkiem $z$, nazywające główny komponent potrawy np. sałatka z pomidorów. W języku bułgarskim występuje struktura z przyimkiem om, który pomimo analityczności języka implikuje tę samą informację co rzeczowniki w dopełniaczu z przyimkiem i może być uznany za formę ekwiwalentną caлата om моркови, коктейл от домати.

- Polską i bułgarską ekwiwalencję wykazuje struktura oparta na rzeczowniku (w języku polskim $\mathrm{w}$ narzędniku) $\mathrm{z}$ przyimkiem $z$ nazywającym typowy składnik dodatkowy np. makaron z kurczakiem, rosót z makaronem, качамак с шунка, сарми с петел.

- W funkcji atrybutywnej $\mathrm{w}$ tytułach przepisów zarówno polskich jak i bułgarskich występują także rzeczowniki w miejscowniku z przyimkiem $w$ np. raki w piwie, kasztany w mleku, яйиа в домати.

- W nazwach dań występują także imiesłowy przymiotnikowe np. smażony pstrag, вита баница.

W języku polskim występują także dwie dodatkowe struktury, mianowicie:

- rzeczowniki w narzędniku z przyimkiem pod, np. sznycel pod beszamelem;

- rzeczowniki w miejscowniku z przyimkiem na krem na mleku.

Przytoczone przykłady konstrukcji przepisów kulinarnych świadczą o ich dużej różnorodności i trudności w jednoznacznej klasyfikacji.

Wiele tytułów współczesnych bułgarskich przepisów kulinarnych odnosi się do realiów kulturowych, które bądź wywodzą się ze starobułgarskiej kultury i sztuki kulinarnej, bądź zostały w niej zakorzenione przez inne narody z biegiem czasu i przez wydarzenia historyczne.

Jest to wiedza istotna $\mathrm{W}$ procesie przekładu, ponieważ umiejętność odpowiedniego dopasowania lub zmiany struktury tytułu przepisu kulinarnego wiąże się bezpośrednio ze znajomością dyskursu rodzimego i obcego. Skoro przepisy i ich tytułu są elementem kulturowym i nazywają często wytwory kultury, w konkretnych przypadkach można mówić o problemie nieprzekładalności. Opisane powyżej rozważania ilustrują następujące przykłady: 
Problem „względnej” nieprzekładalności występuje w przypadku dania o nazwie капама thum. kapama. Jest to ogólnobałkańskie danie, którego pochodzenie jest jednak tureckie (Мантов 1998: 3). Potrawę tę określa się jako mięsną, chociaż posiada ona wiele wariantów uzależnionych od regionu, kraju, pory roku, czy upodobań kulinarnych. Stałym komponentem jest natomiast mięso oraz kapusta kiszona. Nazwa kapama w języku tureckim również oznacza danie, jednak jego semantyka i morfologia wskazują, że jest to derywat od leksemu kapal, co oznacza zamknięty (затворен). Istotnym składnikiem tego przepisu jest ciasto, nakładane na zapełnione pozostałymi produktami gliniane naczynie - gjuwecz, w celu dodatkowego „Zamknięcia“ i uszczelnienia potrawy, co najpewniej ma bezpośredni związek z etymologią tej nazwy. Tutaj pojawia się trudność w doborze odpowiedniego ekwiwalentu. W Bułgarii i innych krajach bałkańskich nazwa tego dania nie jest tłumaczona ani opatrzona żadnym leksemem o charakterze atrybutywnym, a przyjęta jako zapożyczenie $\mathrm{z}$ języka tureckiego. W podobny sposób może więc zostać przyjęta w kręgu odbiorców polskich. W innym przypadku trudne jest znalezienie określenia, które w sposób krótki i zwięzty opisywałoby charakter tego dania. Transliterację nazwy dania каnaмa trl. kapama uważam więc za najbardziej optymalny zabieg translatoryczny, ze świadomością iż jest to równocześnie zabieg egzotyzacji².

Tytuł пататник również jest dla polskiego odbiorcy, nawet po transliteracji tytułem egzotycznym, jednakże w tym wypadku za odpowiednie uznałam rozwinięcie go w przekładzie na język polski. Głównym składnikiem tego dania są ziemniaki. Jest ono charakterystyczne dla regionu gór Rodopów, do jego produkcji używa się produktów łatwo dostępnych. Może być potrawą mięsną lub jarską. Wybrany do tłumaczenia przepis zawiera instrukcję przygotowania dania bezmięsnego. Danie to, podobnie jak kapama czy gjuwecz, nic nie implikuje polskiemu odbiorcy, posiada natomiast niezmienny składnik główny - ziemniaki. Tę informację można ująć w przekładzie tytułu przepisu. W tym celu należy użyć spójnika służącego do konstruowania wyrażeń wyjaśniających - czyli. Dzięki temu otrzymujemy pełny przekład przepisu na język polski - Patatnik czyli danie z ziemniaków. Aby przybliżyć specyfikę wyżej wymienionego dania Polakowi dokonano amplifikacji ${ }^{3}$ oraz transliteracji. Tym sposobem zachowano realium językowe $w$ postaci przetransliterowanej nazwy głównej, ale dodano informację o jej zasadniczym komponencie.

\footnotetext{
${ }^{2}$ Barbara Z. Kielar uważa zabieg transliteracji za jeden ze sposobów tłumaczenia nazw realiów (Kielar 1988: 92).

${ }^{3}$ Przez zabieg amplifikacji rozumiem uzupełnienie tekstu przekładu o elementy nowe.
} 
Козунак to rodzaj pieczywa określany przez niektóre portale internetowe o charakterze kulinarnym jako słodki chlebek wielkanocny ${ }^{4}$, przez inne - jako bulgarian easter bread (butgarski chleb wielkanocny) ${ }^{5}$. Wszystkie określenia są prawidłowe, ponieważ jest to charakterystyczne danie z mąki i drożdży, przyrządzane głównie w okresie wielkanocnym. Jednakże jego smak, a czasami także wygląd, można porównać do jadanej w Polsce, nie tylko w okresie świątecznym, chałki. Jej obecność w polskiej kuchni można wykorzystać w przekładzie na język polski, zachowując przy tym także nazwę oryginalną, gdyż podobnie jak wiele pozostałych nazw dań Козунак stanowi realium językowo-kulturowe. Aby umożliwić polskiemu czytelnikowi odbiór przekładu, obowiązkowym zabiegiem jest zabieg transliteracji. Po przeanalizowaniu składu tego bułgarskiego wypieku oraz znanej w Polsce chałki, stwierdzam, że są na tyle podobne, iż można je ze sobą porównać. Należy jednak przy tym zaznaczyć, że kozunak jest wypiekiem typowo wielkanocnym, dlatego uznaję za obowiązkowe dodanie takiej informacji w przekładzie. Dokonano tym sposobem transformacji w postaci amplifikacji, przez użycie po myślniku wyjaśnienia - bułgarska chałka wielkanocna. Przekład wygląda następująco: Kozunak - bułgarska chałka wielkanocna.

Кашник (trl. Kasznik), jest jednym z najbardziej problematycznych tytułów, pomimo iż struktura na to nie wskazuje. Dlatego, że jako tytuł jednowyrazowy stanowiący realium kulturowo-językowe, może albo nie komunikować polskiemu odbiorcy nic, albo wręcz wprowadzać błędne asocjacje. Kasznik jest potrawą typową dla regionu rodopskiego, po upieczeniu konsystencją przypominającą chleb, składającą się przede wszystkim z ziemniaków i mąki kukurydzianej. Swoją nazwę zawdzięcza prawdopodobnie swojej konsystencji owsianki w surowym stanie, którą zapieka się w piekarniku. Tytuł nakłania polskiego odbiorcę do asocjacji ze znaną polskiemu odbiorcy kaszą (jako jadalnymi nasionami zbóż). Sam leksem kasza posiada w języku polskim i bułgarskim znaczenia, które generują różne skojarzenia u dwojga odbiorców - polskiego i bułgarskiego. Jak wynika z porównania definicji, 'kasza' w języku polskim i bułgarskim posiada wspólny mianownik semantyczny, który oznacza zamieszanie, chaos, zamęt, a także gotowe danie. Język polski definiuje 'kaszę' dodatkowo jako ziarna zbożowe, natomiast język bułgarski używa leksemu 'kasza' na określenie konsystencji dania. Pojawiają się jednak dwie definicje charakteryzujące opisywany leksem w dwóch różnych kierunkach: w języku polskim to coś sypkiego, w języku bułgarskim natomiast jest to gęsta mieszanka $\mathrm{z}$ jednakowych produktów (np. zmielone

\footnotetext{
${ }^{4}$ Słodki chlebek wielkanocny - Kozunak. Dostęp z: https://www.winiary.pl/przepis.aspx/77106/slodki-chlebekwielkanocny-kozunak (2016-12-11).

${ }^{5}$ Bulgarian Ekster Bread (Kozunak). Dostęp z: http://www.food.com/recipe/bulgarian-easter-bread-kozunak109967, (2016-12-11).
} 
owoce, warzywa $\mathrm{i}$ inne) ${ }^{6}$. Definicje te można uznać nie tylko za różne, ale także przeciwstawne. Sypkie rzeczy zarówno polskiemu, jak i bułgarskiemu odbiorcy ewidentnie kojarzą się z suchym, zmielone natomiast z czymś mokrym. Biorąc pod uwagę te dwie antytezy można stworzyć dwie mapy asocjacyjne dotyczące dania kasznik, jedną - w kręgu kultury bułgarskiej, drugą - w kręgu kultury polskiej, co wpływa na efekt procesu tłumaczenia nazwy omawianego dania. Przepis w spisie produktów potrzebnych do przygotowania tego dania nie zawiera kaszy, dlatego można jednoznacznie stwierdzić, że - jak zostało już wspomniane - nazwa może wywodzić się z jego konsystencji. Ponieważ oczekiwania polskiego odbiorcy względem przepisu zatytułowanego kasznik mogą różnić się od rzeczywistości kulinarnej, można uznać za zasadne rozszerzenie tytułu o wyrażenie atrybutywne: rodopski chleb. Wyrażenie to, oprócz informacji odnoszącej się do rodzaju a tym samym konsystencji dania, zawiera także informację o regionie, w którym danie to jest najbardziej popularne, i z którego pochodzi. Komponent główny tytułu przepisu, stanowiąc element nieprzetłumaczalny w związku z tym, że zalicza się do grupy realiów językowych, został jedynie przetransliterowany. Końcowym efektem procesu tłumaczenia jest: Kasznik - rodopski chleb.

Następnym tytułem poddanym analizie jest tytuł dania o nazwie Млечница брашнена халва. Jest to potrawa $\mathrm{z}$ mleka $\mathrm{i}$ z mąki z dodatkiem orzechów i miodu. Przepis pochodzi z książki kucharskiej Българса празнична трапеза, z rodziału poświęconego potrawom Bożonarodzeniowym (Радева, Кирилова 1991: 23). Јеј oryginalny tytuł zawiera komponent główny - Млечница, a także dodany po myślniku komponent objaśniający брашнена халва. Taka konstrukcja tytułu oryginalnego oznacza, że nawet dla prymarnego bułgarskiego odbiorcy sama nazwa Млечница nie jest do końca jasna, musiała zostać rozszerzona już w oryginale o dodatkowe wyjaśnienie podające informację o rodzaju dania i jego głównym składniku, w tym wypadku mąki. W trakcie procesu przekładu nazwa główna jako element klasyfikujący się do realiów językowych została przetransliterowana, był to jedyny zabieg na komponencie głównym tego tytułu. Dokładne ekwiwalenty pozostałych leksemów występujących w tytule zostały w języku polskim odnalezione i użyte. Produktem procesu thumaczenia jest więc Mlecznica - chatwa maczna.

W Bułgarii bardzo popularne są różnego rodzaju sałatki bądź surówki, dlatego kolejny analizowany tytuł to tytuł dania o nazwie Шопска салата. Sałatki przygotowywane są $\mathrm{z}$ wszelkiego rodzaju warzyw, zarówno świeżych jak i konserwowych (Goszczyńska, Parnowska 1980: 62). Często stanowią dodatek do dań

\footnotetext{
${ }^{6}$ Źródłem opisu są definicje: 'kasza' (Nowy słownik języka polskiego) $i$ 'каша' (Съвременен тълковен речник на българския език с приложения).
} 
głównych, a odpowiednikiem względem kolejności ich podawania w polskiej kulturze może być zupa. W Polsce w wielu domach zupa stanowi swego rodzaju aperitif przed „cięższym daniem”, podobnie wygląda kultura jedzenia sałatek w Bułgarii, co nie oznacza, że nie są spożywane jako osobne danie. Często stanowią przekąskę do wszelkiego rodzaju alkoholu. Шопска салата to jedna z najpopularniejszych sałatek w Bułgarii. Jest to sałatka składająca się przede wszystkim z ogórków, papryki oraz pomidorów z dodatkiem octu. Pomimo swojej tradycyjności шопска салата nie jest potrawą znaną od wieków, jest to wynalazek względnie młody, pochodzący prawdopodobnie z lat 60 . XX wieku. Jego receptura pojawiła się po raz pierwszy w restauracji „Балкантурист” (Бориславов). Nazwa шолска jest derywatem od leksemu uon, który odwołuje się do określenia Bułgarów pochodzących z zachodniej Bułgarii w rejonie miasta Sofia i okolic (Речник на българския език). Stanowiący realium językowe leksem ten jako derywat nazwy mieszkańca regionu został jedynie przetransliterowany: szopska. Nazwy regionów i miejscowości, a także ich nazwy pochodne są elementami zazwyczaj nieprzetłumaczalnymi, jako że region jest przypisany do danego kraju i funkcjonuje tylko w jego obrębie. Nie da się więc go przyrównać do żadnego innego. Przekład musi być w tym wypadku przekładem wiernym, nie adekwatnym. Wynikiem tłumaczenia jest: sałatka szopska.

Przepis nа варено жито jest kolejnym przepisem, którego tytuł został poddany tłumaczeniu i analizie. Danie to jest daniem typowo wigilijnym. Przepis został zaczerpnięty z książki kucharskiej z rozdziału odnoszącego się do dań wigilijnych. Przepis można uznać za minimalistyczny pod względem ilości składników, jest on natomiast czasochłonny. Tytuł ten nie jest wymagający pod względem przekładu. Pomimo że danie to nie jest jadane w Polsce w takiej samej postaci jak w Bułgarii, sama jego przetłumaczona nazwa może wywołać prawidłowe asocjacje względem jego smaku oraz wyglądu ${ }^{7}$. Tytuł składa się $\mathrm{z}$ dwóch komponentów, rzeczownika i występującego w roli atrybutywnej przymiotnika. Leksem варено posiada swój dokładny odpowiednik w języku polskim, który po zmianie rodzaju gramatycznego, czego wymaga rzeczownik, brzmi: gotowana. Жumo natomiast, oprócz tego że jest to leksem całkowicie przekładalny, należy też do grupy tzw. faux amis. Oznacza więc nie zyto a pszenice. Końcowym etapem procesu przekładu jest tłumaczenie: gotowana pszenica.

Oryginalny przypadek w procesie tłumaczenia stanowiła nazwa dania: фасул чорва. Przepis ten został zaczerpnięty z książki kucharskiej pt. Българска празнична

\footnotetext{
${ }^{7}$ Danie to można porównać z polską kutia. Kutia w Polsce składa się z gotowanej pszenicy (którą mogą też zastąpić różnego rodzaju kasze) oraz z bakalii i przede wszystkim maku, którego brakuje w bułgarskim przepisie na варено жито.
} 
mpaneзa. Tytuł ten składa się z dwóch zasadniczych komponentów, przy czym obydwa leksemy są rzeczownikami. Pierwszy rzeczownik rodzaju męskiego - фасул przejmuje rolę atrybutywną. Чорва natomiast jest rzeczownikiem rodzaju żeńskiego. Stanowi on niewątpliwie realium językowo-kulturowe, a jego przekładalność zależy od kontekstu w jakim występuje ${ }^{8}$. Konstrukcję tytułu tego przepisu można uznać więc za niestandardową. Ważnym jest fakt, że przepis ten wpisuje się w narodową, tradycyjną kuchnię bułgarską. Tytuł jest pewnego rodzaju kolokacją. Łamie zasadę kongruencji podobnie jak леща чорва, ponieważ rodzaj gramatyczny komponentu głównego nie zgadza się z rodzajem komponentu określającego, który powinien być przymiotnikiem a nie rzeczownikiem. Leksem фасул posiada swój ekwiwalent w języku polskim: fasola szparagowa, natomiast чорва wykazuje wariantywność, może zostać przetłumaczona jako zupa, natomiast nie jest z nią tożsama i stanowi realium językowe. Dlatego w tym wypadku za słuszną uznałam transliterację zamiast wyrażenia uogólniającoprzybliżającego, aby zachować element egzotyczności. Przepis, którego tytuł jest poddawany analizie, traktuje o fasoli, ale szparagowej. $\mathrm{Z}$ wyrażenia fasola szparagowa, jako że jest to dwuczłonowa nazwa własna rośliny nie da się utworzyć przymiotnika ponieważ samo określenie szparagowa już nim jest. Za zasadną uznaję w tym wypadku amplifikację. Dodając przyimek $z$ i rozszerzając pojęcie czorba o wyrażenie atrybutywne, nazywające główny komponent, uzyska się thumaczenie: Czorba z fasoli szparagowej, zachowując sens i znaczenie oryginalnego tytułu oraz informując polskiego odbiorcę o rodzaju dania. Pozostawienie wyrazu czorba, poddanego jedynie transliteracji, niewątpliwie jest egzotyzacją $w$ odbiorze. Jest to jednak zbyt charakterystyczna potrawa w bułgarskiej kuchni, aby ja naturalizować. Tę rolę pełni wyjaśnienie dotyczące głównego składnika potrawy.

Stosunki, które w języku bułgarskim wyraża się za pomocą przyimków w języku polskim, często wyrażane są za pomocą przypadków. Niektóre z przyimków bułgarskich posiadają swój dokładny ekwiwalent w języku polskim, natomiast istnieją też takie, które wykazują odmienne znaczenie (Popowa 2009: 143). Tę zależność można wskazać na poniższych przykładach tytułów przepisów kulinarnych. Znaczną część tytułów przepisów wybranych do tłumaczenia zawierających przyimek stanowią te zawierające konkretny przyimek $c$. Ekwiwalentem tego przyimka w języku polskim jest przyimek $z$. W przepisach łączy on zazwyczaj nazwę głównego dania z nazwą jednego

\footnotetext{
${ }^{8}$ Autorki książki „,Z pomidorem w herbie” określają czorbę jako pikantną zupę, która może być podawana zarówno na ciepło, jak i na zimno ${ }^{8}$. Supa natomiast również jest określeniem zupy rozumianej jako płynne danie, zazwyczaj stanowiące pierwsze danie obiadowe, które od czorby odróżnia sposób przygotowania. Czorbę gotuje się na „małym ogniu”, łącząc od razu wszystkie produkty, supę natomiast przygotowuje się w wysokiej temperaturze, dodając składniki stopniowo ${ }^{8}$. Czorbę można podawać jedynie z kawałkami mięsa, podrobami, z warzywami bądź z ryżem, natomiast supę łączy się z kluskami lub makaronem (Goszczyńska, Parnowska 1980: 9).
} 
z jego składników, np. kaczka $z$ jabłkiem. Polski przyimek $z$ łączy się także $\mathrm{z}$ dopełniaczem, np. krem $\mathrm{z}$ dyni, wtedy jednak ekwiwalentem w języku bułgarskim będzie przyimek $o m$.

Jednym z kilku tytułów poddanych tłumaczeniu jest качамак с картофи. Jest to tradycyjne danie bułgarskie, składające głównie z ziemniaków z dodatkiem mąki kukurydzianej. Istnieje kilka wariantów tego dania. К. Мериджанов podaje także przepisy na: качамак с шунка, качамак с тиква, качамак с орехи, качамак по овчарски itd., (Мериджанов 1992: 24-26). Mоże on zastępować pieczywo oraz być podawany na słono lub słodko. Wybrany przepis opisuje sposób przygotowania tego dania na słono. Sama nazwa własna - качамак, stanowi element realiów kulturowojęzykowych. Została więc ona jedynie przetransliterowana - kaczamak. Kapmoфu jako nazwa warzywa posiadająca swój ekwiwalant w języku polskim została przetłumaczona jako ziemniaki. Ponieważ sama nazwa качамак niewiele mówi polskiemu odbiory, zdecydowano się na zmianę w strukturze tytułu. Wyrażenie określające składnik atrybutywny wraz z przyimkiem $c$ (z ziemniakami) zamieniono na przymiotnik określający główne danie - ziemniaczany, podając tym samym informację o zasadniczym i charakterystycznym składniku tego dania. Wynikiem procesu tłumaczenia tego tytułu jest: ziemniaczany kaczamak, co pomimo zmiany struktury oryginalnego tytułu przepisu oddaje jego sens i znaczenie.

Ostatnim omawianym tytułem jest nazwa dania, w której występuje przyimek $\mu a$, wpisując się tym samym w grupę tytułów przepisów, które informują o sposobie przygotowania potrawy - Kюфтета на скара. Скара, posiadając swój ekwiwalent funkcjonujący w języku polskim: grill, nie sprawia tłumaczowi problemu. Przyimek $н а$ poprzedzający nazwę urządzenia służącego do obróbki cieplnej oznacza, że potrawa jest przygotowywana za pomocą tego właśnie urządzenia. Strukturalnym i kontekstowym odpowiednikiem tego przyimka będzie w tym wypadku przyimek $-z$. Najistotniejszym elementem tego tytułu jest leksem кюфтета (1.m.), stanowiący realium kulturowe. Kюфme (1.p.) to danie ze zmielonego mięsa, o charakterystycznym smaku, podawany zazwyczaj w formie owalnej. Jako że przetransliterowana nazwa - kjufteta nic nie implikuje polskiemu odbiorcy, postanowiono zastosować w języku przekładu pojęcie uogólniająco-przybliżone (Kielar 1988: 92) w formie deminutywnej - klopsiki. Aby jednak nie zatracić istotnej cechy tego dania jaką jest bułgarskość, dodano to określenie do nazwy dania9 ${ }^{9}$ Końcowym efektem procesu przekładu jest tytuł: bułgarskie klopsiki z grilla.

\footnotetext{
${ }^{9}$ Za tertium comparationis posłużyło charakterystyczne pod względem formy szwedzkie danie, wypromowane przez szwedzką sieć sklepów - klopsiki szwedzkie.
} 
Po przeprowadzonej analizie przekładu tytułów przepisów kulinarnych można stwierdzić, że pewne struktury są w języku polskim i bułgarskim tożsame pod względem formy, jednakże nie zawsze oddają ten sam sens. W celu jego zachowania, a też zachowania znaczenia czasami konieczna jest zmiana struktury lub/i transliteracja, niekiedy z amplifikacją. Redukcja nie została zastosowana $\mathrm{w}$ żadnym z opisywanych przykładów, ponieważ oprócz braku potrzeby nie powinno jej się stosować przy przekładzie, który nosi w sobie wartość kulturową, Wartość kulturowa, ze względu na dużą różnorodność podmiotów kulturowych zawsze stanowi wartość dodaną. Zabiegi amplifikacji stanowiły rozszerzenie tekstu o ekwiwalent funkcjonalny, pozwalający na odpowiedni odbiór a przekształcenia powodujące egzotyzacje dokonywane były w celu zachowania elementu kultury wyjściowej.

Reasumując, w procesie przekładu tytułów niezbędne okazały się transformacje, pomagające $\mathrm{w}$ procesie naturalizacji niektórych nazw. Pojawiły się też transformacje nazw, których etymologia i zakorzenienie w tradycji bułgarskiej jako odrębnej od polskiej nie pozwalają na proces udomowienia, a egzotyzacja, najczęściej w formie zachowania ich nazwy, stanowiła najlepsze rozwiązanie.

Wszystkie transformacje zaistniałe podczas procesu przekładu tytułów przepisów kulinarnych zostały dokonane w taki sposób, aby były one dla polskiego odbiorcy zrozumiałe i przekazywały istotne informacje na temat dań, nie pozbywając ich przy tym roli nośnika kultury bułgarskiej.

\section{Summary}

This article presents the possibilities of translating the titles of Bulgarian recipes into Polish. The article is divided into two parts. The first - theoretical, describes the concept of title in the context of the recipe. The structures of Polish and Bulgarian titles were described. Attention has been paid to elements of the text that may cause a problem during the cultural translation. In the practical part, have been shown examples of translations, including commentary related to the translation theory.

\section{Literatura}

Goszczyńska, A., Parnowska, H. Z pomidorem $w$ herbie, kuchnia butgarska. Warszawa: WATRA, 1980.

Kielar, B. Z. Thumaczenie i koncepcje translatoryczne. Wrocław: Zakład Narodowy im. Ossolińskich, 1988. 
Popowa, W. Zwięzła gramatyka języka bułgarskiego. Warszawa: Wiedza Powszechna 2009.

Sobol, E. (ed.) Nowy słownik języka polskiego PWN. Warszawa: PWN, 2002.

Żarski, W. Książka kucharska jako tekst. Wrocław: Wydawnictwo Uniwersytetu Wrocławskiego, 2008.

Буров, С. (ed.) Съвременен тълковен речник на българския език с приложения. Велико Търново: Слово, 2019.

Мантов, Д. Българска традиџионна кухня, София: Май, 1998.

Радева, Л., Кирилова, А. Българска празнична трапеза. (Обичаи и традиционни готварски рецепти), София: Май, 1991.

\section{Źródla internetowe}

Бориславов, Я. Как се e появила шопската салата. Dostęp z: http://www.menumag.bg/za-hranata/statii/kak-se-e-poyavila-shopskata-salata 2017-01-06).

Речник на българския език. Dostęp z: http://ibl.bas.bg/rbe/lang/bg/шоп/ (2017-06-02).

Dostęp z: http://www.food.com/recipe/bulgarian-easter-bread-kozunak-109967 (201612-11).

Dostęp z: https://www.winiary.pl/przepis.aspx/77106/slodki-chlebek-wielkanocnykozunak (2016-12-11). 